\title{
RATING OF MĀORI LAND: A LEGAL HISTORY
}

\author{
RP Boast*
}

This article deals with the rating of Māori freehold land as a case study of a field of law where Māori Land Law and Taxation Law overlap. Rates, are, of course, a type of tax. For Māori landowners, paying rates and rates debts were probably the most important tax-related problem they had to confront. The issue was not only that Māori landowners often could not afford to pay rates. While that was the case, the real issue was the overlay between Māori land law and tax law as such. The real problem with rating of Māori land was the Māori land law system itself. This article explains why this is so, and utilises rating law as a window into the complexities of the statutory Māori land law system and the complexities it caused to Māori landowners.

\section{INTRODUCTION: MĀORI FREEHOLD LAND}

Rating of Māori land is where tax law and Māori land law meet. That is because Māori difficulties with paying rates did not arise merely because they could not afford to, or because Māori were reluctant to pay rates to county councils that were often neglectful of Māori needs. While that was all certainly the case, the real problem was at the same time deeper and more complex: the fundamental issue was the problem of Māori land tenure itself. By that, I do not mean that the problem lay in the supposedly "customary" or "collective" nature of Māori tenures. By the 20th century Māori customary law and the traditional or customary law of Māori land tenures had long ago parted company. Māori land law was based on statute, not on custom. ${ }^{1}$ By 1910 , the statutory system was already truly labyrinthine, deriving originally from the Native Lands Acts of 1862 and 1865, but since then having been the subject of near-constant remodelling. Māori land law was the state's own creation, and the problems relating to rating of Māori land were the creation of the government and of statute. No less irrelevant was, and is, the common law of native or aboriginal title, of great juristic interest, but of little practical importance when it comes to Māori land law as it operates. For Māori land in New

* QC, OMNZ, Professor, Te Herenga Waka | Victoria University of Wellington. Research for this article was conducted as part of a research project by the author and Alex P Boast in 2020-2021 for Ngati Raukawa it e Tonga, supported by the Crown Forestry Rental Trust.

1 On the origins of the Māori land system see R P Boast The Native Land Court 1862-1887: A Historical Study, Cases and Commentary (Thomson Reuters, Wellington, 2013). 
Zealand, it has been legislation which counted, not the ancient wisdom of the common law. The common law is no less irrelevant to the practicalities of Māori land law than it is, for example, to the modern law relating to income tax. If New Zealand law relating to income tax is a statutory maze, so too is Māori land law. Those interested in Māori issues and the law who choose to focus on the common law of Native Title or on the slow elaboration by the Courts of the Principles of the Treaty of Waitangi may still be able to see the law as in some way redemptive; those who try to cut their way through the harsh thickets and thorns of statutory Māori land law can have no such illusions.

It is possible to discern some foundations underpinning the statutory edifice, however. The Māori land law system is based around some basic legal structures and institutions, the first a category of land, and the other, a very special Court. The category of land and the special Court interlock: the Court deals with a particular category of land, and the category of land is something the special Court has made. The category is one familiar to New Zealand property lawyers: that of Māori freehold land. Māori freehold land is defined as "land, the beneficial ownership of which has been determined by the Maori Land Court by freehold order". ${ }^{2}$ Māori freehold land, is, for most purposes, what "Māori land" is. The special Court is, of course, the Māori Land Court (originally the Native Land Court). Māori freehold land is the category of land that the Māori Land Court has made, and the Court's principal jurisdiction is over Māori freehold land. Both Court and land category are creations of statute, that is to say, creations of New Zealand's highly politicised legislature. The Native Land Court was the anvil, or the furnace perhaps, on (or in) which Māori freehold land was forged.

By the 20th century, the category of Māori freehold land had stabilised, meaning land that had been investigated by the Native Land Court and its owners defined (whether adequately or not), and subsequently Crown-granted, or - which amounts to the same thing - the subject of a certificate of title under the Land Transfer Act. It is a mistake to think that the Māori land system sits outside the Torrens system because, in reality, Māori freehold land fits within the Torrens system; Māori freehold land is all Torrens System land (only Māori customary land - which essentially exists only nominally - is not). In modern times the issues relating to Māori land concern the practical day-to-day problems of a stabilised class of land titles, which account for about 20 per cent of the North Island. The first set of problems related, and still relate, to problems with the original title itself, the titles usually said to be "crowded" (that is, with too many individual owners). Another issue for most of the 20th century were the Māori Land Boards, responsible for administering a sub-category of Māori freehold land, Māori "vested lands", meaning Māori freehold land which for various reasons had been vested in a Land Board. The Māori owners had little ability to manage their own property after it had been vested.

2 Te Ture Whenua Maori | Maori Land Act 1993, s 129(2)(b). The definition, while clear and strictly accurate, gives little idea of the complexity of this category of land. Such land is land that has been investigated by the Māori Land Court from time to time, and which has, following investigation, been converted by various means into Crown-granted freehold titles, the legal owners being those individual owners and their descendants as determined by the Native/Māori Land Court. 
Typically, vested land was leased by a Land Board to Pākehā tenants on long-term leases, which the Boards collected and distributed to the owners.

Finally, there was the Crown purchasing system. ${ }^{3}$ The government continued to purchase Māori freehold land, which it had to do by buying up individual shares and applying to have Māori freehold lands partitioned in the Land Court between Crown and "non-seller" sections. While Crown purchases were in train, which could often take years to be resolved, owners were subject to numerous restrictions. Above all this was superimposed the problem of paying rates. The problem of rating commingled with all the other difficulties. If land had been vested in a Land Board, where the owners really had little or no control over their own property, which party was liable for rates? The disempowered owners? Or perhaps the Land Board, or perhaps the lessee, or all three maybe? If land was being targeted for Crown purchase and the Crown had "proclaimed" it, or had acquired a significant amount of the shareholdings, then ownership was divided between non-sellers and the Government. The Crown purchased vested land too, combining an array of uncertainties. One can see, then, that the matter of Māori land rating was not so much about Māori unwillingness to pay as it was about the system itself.

\section{RATING AND THE MATORI LAND SYSTEM}

New Zealand inherited its system of local authority finance from England, where county and borough councils had for centuries been supported by rates. Rates are of course simply a tax mandated by law payable by property owners to local government, a system perhaps more suitable for a decentralised country, such as early modern England, than a New World country like New Zealand. In England, rates had funded the "Poor Law", the closest thing that existed to social welfare (the Poor Law has long been a subject of the deepest interest to social historians ${ }^{4}$ ). Rates link local government services directly to the ability of property-owners to pay; a reason for the wretched poverty and dilapidation of Ireland was that the Irish peasantry was too poor to pay rates, and as a result, few rural services existed. In England, rates had even paid for the county jails, as government-run prisons did not exist until 1819, meaning that the state of prisons and the ability of prisoners to survive incarceration was regionally highly variable, to put it mildly. Modernising and remodelling the whole system of local body finance in New Zealand was apparently too complex and revolutionary to be contemplated. Hospitals, too, were for many years supported by rates, supplemented by fees paid by patients, perhaps a relic of the old English Poor Law. New Zealand's Health Department mainly played

3 On the operation of the Crown purchasing system for Māori land after the enactment of the Native Lands Acts and the establishment of the Native Land Court, see Richard Boast Buying the Land, Selling the Land: Governments and Maori Land in the North Island 1865-1921 (Victoria University Press, Wellington, 2008).

4 See for example Gertrude Himmelfarb The Idea of Poverty: England in the Early Industrial Age (Faber and Faber, London, 1984). 
a coordinating role, liaising with the hospital boards and the New Zealand branch of the British Medical Association (the latter was basically a trade union for doctors).

Māori land law was not, and indeed still is not, a rational structure. Rather, it was a disorganised heap of particulars. It had no logical design or organising principle: it was underpinned by no noble or inspiring ideals whatever; nor did it even have any cunning or malevolent aspirations. It was merely layer upon layer of statute, each layer a response to the one immediately before it, constantly patched, chipped away at, and filled in. The massive codifying 1909 Native Lands Act, a more thoughtful effort than most, did not change its basic character. The law had this character because Māori land law was about land (obviously), a subject that a very politicised legislature, ready to enact statutes at any moment, cared about a great deal (while caring about Māori much less). The law could not make sense because its components had discordant objectives: one objective was to ensure that enough Māori land could be sold to keep the Māori land market ticking over; another was to privilege the state in the Māori land market over the private sector; and the third objective, pursued without thinking too hard about it, was to do something to save the Māori people from themselves. The core of the system was composed of the Native Lands Acts (1862-1865), which were repeatedly amended and reenacted, and the Native Land Court, the former being the conceptual foundation of the structure, to the extent there was one. By 1900, that original foundation of statute had become so massive, buried beneath so many layers of statute, that very little of the original structure built in 1863-1865 could be discerned.

The Native Rating Act of 1904 made all Māori freehold land rateable, usually at half of the usual rate. The 1904 Act simplified an earlier baffling system of Māori land rating under the Rating Acts Amendment Acts of 1893 and 1896. Under the 1904 Act, defaulters might find their land compulsorily vested in a Land Board, which could lease the land and pay off the debt, at which point it could be returned. Local bodies, typically - especially in the case of the county councils - the mouthpieces of Pākehā rural settlers, were much exercised by the growth of arrears of rates on Māori land.

The problems relating to rates were immediate and practical. Māori owners often did not, or could not, pay rates, which would mean that local bodies would secure charging orders under the Native Land Rating Act 1924 against Māori land blocks in the Native Land Court. ${ }^{5}$ These orders only made things worse as charged blocks were inalienable. ${ }^{6}$ Local authorities expended much energy in trying to turn "the Native rating problem" into a major political issue. ${ }^{7}$ Local authorities sometimes argued

5 T J Hearn Land titles, land development, and returned soldier settlement in Te Rohe Pōtae (Wai 898, 2009) A69 [Te Rohe Pōtae Inquiry] at 27-39. Charging orders could be obtained under the Native Land Rating Act 1924, which prohibited any further dealings with the land until the rates had been paid, "adding", as Hearn rightly notes, "further to the difficulties with which Maori land owners were compelled to deal."

6 Which meant in practice that such lands could only be sold to the Crown. Māori owners thus were not always able to easily sell land to discharge rating debts, should they have been driven to that extremity.

7 Hearn, above n 5, at 27. 
that the Crown should pay unpaid rates on Māori land, or at least the difference between rates levied and what the Councils had been able to collect. Unsurprisingly, the government was unenthusiastic about what it saw as a blatant attempt by farmer-dominated local bodies to obtain revenues from general taxation.

Farmers' organisations demanded that the state should end all protection mechanisms for Māori land, that the state should aggressively purchase what unalienated Māori lands remained, sell these lands to themselves (farmers), that all Crown lands should be surveyed and offered for sale to farmers, that tariffs should be reduced or eliminated, and that Māori owners should be forced to pay rates. These views encapsulated farmers' narrow vision that they and they only counted in the national economy and that whatever benefited farmers was ipso facto good for the nation. At the Farmers' Union annual conference in 1915 these views were made very clear: ${ }^{8}$

\footnotetext{
At the Farmers' Union Conference it was resolved that the Government be asked (1) To acquire as much unoccupied native land as possible each year and offer it for settlement; (2) to repeal the Urewera Native Reserve Act and throw open for settlement the Urewera country; (3) put on the market at once all lands already purchased from the natives in the Urewera country; (4) to throw open for selection all Crown Lands as soon as they are surveyed; (5) that Native lands which benefit from expenditure of special and general rates shall be placed upon same footing as European lands situated.
}

Rating and land title were interlocking problems. Local authorities strongly favoured the alienation of Māori land to settlers (who could, it was thought, be relied on to pay rates) or failing that, it should be transferred to the Māori Land Boards. Usually, Māori owners did not pay because they had no money, the problem being compounded by crowded titles, but there was also a feeling amongst many in the Māori community that councils made little effort to provide adequate services for rural Māori communities. In fact, there is little evidence of any Māori collective effort to boycott paying rates, while there is certainly evidence of Māori annoyance about some of the rather hard things farmers and local authorities had to say.

Māori argued that it was unfair that rates should be levied on unproductive land. Irritated by local body complaints about noxious weeds and pests on Māori land, Māori landowners pointed out that it was not Māori who had foolishly imported gorse, blackberry, and rabbits into the country. Councils persistently harassed the government to provide extra mechanisms of enforcement, but the government was hesitant. Māori, for their part, regarded any attempt to take land in recompense for unpaid rates as confiscatory. Sir Apirana Ngata, who became Native Minister in 1929, well aware of the complexities of the issue, had to invest a great deal of effort in negotiating compromise agreements

8 "Farmers' Union Conference" Rangitikei Advocate and Manawatu Argus (Manawatū-Whanganui, 28 July 1915) at 6. 
between councils and owners. The rates problem was another reason why Ngata felt that Māori land development financed by government loans was essential. Moreover (as Ashley Gould has put it): ${ }^{9}$

[f]or Ngata the ability of Māori landowners or communities to meet their rating obligations was one of the tools he used to convert a sceptical press and public to the benefits of Māori land development.

The Māori land rating issue was complicated and led to a number of commissions of inquiry from $1928-1933$ as can be seen in the table below.

Table 1: Principal inquiries relating to Māori land rating

\begin{tabular}{|c|c|c|c|}
\hline $\begin{array}{l}\text { Consolidation } \\
\text { Commission or } \\
\text { Committee of Inquiry }\end{array}$ & 1928 & $\begin{array}{l}\text { To deal with consolidation } \\
\text { of interests of Māori in } \\
\text { Māori lands in North } \\
\text { Auckland and the King } \\
\text { Country (also considers } \\
\text { rates). }\end{array}$ & \\
\hline $\begin{array}{l}\text { Otaki Borough Inquiry } \\
\text { (Commission of Inquiry } \\
\text { re Borough of Otaki) }\end{array}$ & 1928 & $\begin{array}{l}\text { To inquire into rating and } \\
\text { other issues at Ōtaki. }\end{array}$ & $\begin{array}{l}\text { Report at [1928] AJHR } \\
\text { H-28. }\end{array}$ \\
\hline $\begin{array}{l}\text { Commission of Inquiry } \\
\text { into Rating of Farm } \\
\text { Lands in Boroughs }\end{array}$ & 1928 & $\begin{array}{l}\text { Rating of farmlands within } \\
\text { boundaries of boroughs, } \\
\text { particular focus on Feilding. }\end{array}$ & [1928] AJHR H-27. \\
\hline $\begin{array}{l}\text { Native Rating } \\
\text { Commission }\end{array}$ & 1933 & Rating of Māori land. & \\
\hline
\end{tabular}

Why was it all so difficult? Rating of Māori land was surrounded by a thicket of legal and conceptual problems, which were repeatedly debated throughout the 20th century. One key problem was that of Crown "protection mechanisms", in particular alienation restrictions. Māori argued that because they could not alienate their land, which meant that they could not even freely mortgage or lease it, it basically had no value, and as a consequence, should be exempted from rates. This issue went to the heart of rateable values. What was "inalienable" (that is, alienable only to the Crown) land actually worth, if anything? These questions were long-standing. As early as 1905, Māori owners in the King Country were arguing before rating assessment tribunals that because of alienation restrictions, their land had no value under the Valuation of Lands Act 1900. It was agreed that this

9 Ashley Gould Maori Land Development Schemes: Generic Overview c 1920-1993 (Doc\#A67, report commissioned by the Crown Forestry Rental Trust, 2004, Wai 1200 [Central North Island Inquiry]) at 33. 
was a point of such importance that a ruling from the Supreme Court was required. One King Country case was reported in the Waikato Independent (1 June 1905): ${ }^{10}$

At the Assessment Court at Otorohanga, Mr Northcroft, S.M., presiding, a Maori landowner objected to his valuation on the ground that the land in question, being inalienable in common with all other Maori lands in the district, had no selling value. He drew the attention of the Court to the Native Land Court Act of $1894,{ }^{11}$ which imposed restrictions on all the Kawhia County, and stated that many attempts had been made by deputations of owners to the Government in Wellington, and to Ministers locally, to get the restrictions removed, but without success. In this case the owner was unable to occupy or improve his land owing to lack of capital. The Court expressed the opinion that the land in question, being under restrictions which made it inalienable, had no selling value as laid down by the Valuation of Lands Act, 1900, but suggested that the Supreme Court should be appealed to [sic] decide this point. This question opens up a very large question, and one that will have to be settled by a proper tribunal sooner or later. The Maoris present at the hearing at once began to collect money to enable them to be properly represented when the case comes before the Supreme Court.

One can see the point. Who should pay the rates while the Crown blighted the land with alienation restrictions to facilitate Crown purchasing programmes, which could run on for years or (sometimes) decades?

Certain sectors of opinion within the Pākehā farming community and amongst local authorities developed a set of stock attitudes about Māori landowners: Māori landowners, it was said, let noxious weeds spread on their land and failed to pay their fair share of the rates. While it was probably the case that rural counties with large areas of Māori land found it difficult to maintain sufficient income to maintain rural infrastructure, Māori people, who were well aware of what was sometimes being said, resented these accusations. Māori land was afflicted with tenurial problems that rural land in general title was not burdened with: much Māori freehold land was leased; much of it was under Land Board control; other areas were subject to Crown alienation proclamations that hampered access to development credit; and everywhere Māori farmers had low incomes (not quite all: the wonder is that, despite everything, some Māori farmers were quite successful). At meetings of local authority associations there could be much fulmination about Māori landowners, noxious weeds, and rates (and calls for government action). An early example is a meeting of Taranaki local authorities in 1907, commented on by a Manawatū local paper: ${ }^{12}$

A series of resolutions passed at the Taranaki Local Bodies' Conference relative to native land rating and kindred matters were brought before the Acting-Premier to-day by a deputation. Mr Hall-Jones, in reply,

10 "An Important Maori Case" Waikato Independent (Cambridge, 1 June, 1905) at 5. Whether the issue in fact made it to the Supreme Court I have not (so far) been able to discover.

11 Or perhaps the Native Land Alienation Restriction Act 1884 was meant.

12 "Native Land: Rating and Noxious Weeds" Feilding Star (Fielding, 26 April 1907) at 4. 
said that native land rating and noxious weeds questions were of importance, and he believed the Native Land Commission was approaching a stage when it would deal with both matters. It was very certain that they could not go on allowing noxious weeds to grow and spread over native lands or other lands, or allow native lands to escape without paying something towards the upkeep of the roads. The noxious weeds question would have to be dealt with promptly, and if there was no power to make natives do the work, it would have to be done by the Government, and cost borne by the land, and not by the general taxpayers. As regards the roading question, he realised the disadvantage to the country of amending the law. 'We are determined,' he added, 'that this has got to be brought to an end, and the land be made reproductive and made to bear its burden of the cost.' He hoped these matters could be the subject of recommendations by the Commission.

There was no single government strategy in response to these issues, because - like so many tenurial problems of the day - they were all deeply politicised. The extent to which government listened to the laments of farmers and county councils depended on whether a conservative or Leftist ("Lib-Lab" or Labour) government was in power. Conservative Ministers of Lands and Agriculture had to respond to their conservative rural base. The Māori land rating issue was a rural issue, as Māori did not own land in large cities like Auckland and Christchurch; while some believed that it was an ethnic problem ("Natives" did not pay their fair share), in fact it was a tenurial problem, yet another consequence of the Māori land system. Even that, too, was misinterpreted: many Pākehā still believed that the problem was Māori "communalism" and that the remedy was further individualism, while in fact the Māori land system was a creation of the state, and because of conflicting policy demands, was in a constant state of legal flux. Given the fulminations of the Taranaki local authorities at their 1907 conference, it is ironic that nowhere was the Māori land tenure mess as intractable as it was in Taranaki, which many Taranaki farmers would have had cause to know, many of them farming on leaseholds deriving from Māori reserved land blocks. ${ }^{13}$

It was reasonably well understood that some Māori land was of no value, and amendments to the rating code took some account of that. Section 104 of the Rating Act 1925 enabled the removal of valueless parcels of Māori land from the rating rolls by the Governor-General Council and so exempting them from rateability. The procedure was a cumbersome one, but the problem was less that Māori land was valueless more that it was entangled in tenurial complexities and restrictions, the

13 Taranaki had a Māori land tenurial system peculiar to itself, deriving ultimately from the Taranaki confiscation of the 1860s and the West Coast Settlement Act 1880 and the West Coast Settlement Reserves Act 1881. Much Māori land in Taranaki was leased to Pākehā farmers on long-term leaseholds, the leaseholds being administered first by the Public Trustee and then by the Native | Māori Trustee. On the problems of Māori land tenure in Taranaki see Richard Boast The Native/Maori Land Court: Vol 3, 1910-1953: Collectivism, Land Development and the Law (Thomson Reuters, Wellington, 2019) at 327-344. In 1963 the remaining Taranaki Māori leasehold titles were amalgamated by the Māori Land Court and later constituted into the Parininihi ki Waitotara Reserve. On the current situation in Taranaki see Dion Tuuta "Perpetual Leasing in Taranaki, 1880-2008" in R P Boast and R S Hill (eds) Raupatu: The Confiscation of Maori Land (Victoria University Press, Wellington, 2009) 400 at 235-242. 
effects of which varied from place to place, and which must have been very difficult to assess. (Even today, it is widely known that a parcel of Māori freehold land has a lower value than an equivalent parcel in general freehold title but quantifying this is far from easy.) The report of the 1933 Committee on Rating of Native Land found that "very little appears to have been done" under s 104 of the 1925 Act. ${ }^{14}$

Local bodies were very prone to complaining about how much rating arrears on Māori land was costing them. It was often suggested that unpaid rates were costing local authorities a staggering amount. Some of the comments do reflect something of a "them and us" approach ("the natives used our roads, hospitals, schools, and it was high time their lands bore a share of the cost"). On the other hand, some Pākehā and private individuals and local body officers could see that the real author of the problem was the government, because of the confusing system of Māori land tenure and its inaction on making Māori land more productive (the very thing AT Ngata was concentrating on at this time). One well-informed councillor, a Mr Darby (Matamata CC), pointed out was that "recourse on the occupier and the owner were quite different things." Liability to pay rates on Māori freehold land was a complex problem, given that much Māori freehold land being leased. ${ }^{15}$ Who should pay the rates, lessor or lessee?

The issue of the reluctance of Māori to pay rates because of Māori feeling that they did not get adequate rural services needs to be stated with more precision. This was primarily a matter of local government power and priorities and was complex. The real problem was that Māori could not control what local government prioritised. Money paid on rates simply went into the council's general fund, it being up to the council to decide where it built roads, culverts and bridges. There were instances where Māori offered to pay their rates arrears on the condition that the council would construct a road to areas of concentrations of Māori freehold land, and of the Council refusing to do that. This happened at Reureu in the Manawatū, where Māori landowners, unable to persuade county council to build a bridge connecting their properties to the rural road network, built the bridge themselves. ${ }^{16}$ Māori could not strike bargains with councils to carry out particular projects, and in the case of most Councils, Māori landowners lacked political power to influence Council spending. If Councils looked as if they were spending too much on building access routes to Māori blocks, no doubt Pākehā ratepayers would have something to say about it.

The rating problem interconnected with problems of representation. Māori were seldom able to be elected to county councils. The situation was slightly different for boroughs which had a more democratic one-man, one-vote franchise. However, nearly all Māori freehold land was located in the counties, where the rules relating to voting in county elections came perilously close to voter

14 "Report of the Committee on Rating of Native Land" [1933] I AJHR G-11 at 2.

15 "Native Rating Problems: Astounding Losses" Matamata Record (Matamata, 14 November 1927) at 4.

16 "The Reureu Road" Feilding Star (Fielding, 7 July 1914) at 2. 
suppression. It was not until 1944 that all residents of counties were able to vote in county council elections (before then, the county franchise had been confined to the occupiers named on the valuation rolls). Counties continued to be less than democratic. The Local Elections and Polls Amendment Act 1944 finally allowed all residents of counties to vote, ${ }^{17}$ but weighted voting continued. The weighted scale did not finally disappear until the Counties Amendment Act 1974.

Māori were prepared to be reasonable about rates, but consistently called for a better understanding of the interconnected tenurial and economic problems that Māori rural landowners had to put up with. At an important conference of Māori national representatives hosted by Ngati Raukawa at Motuiti in 1928, at which Sir Apirana Ngata was present, it was suggested that special legislation be enacted exempting some categories of Māori land from rating. ${ }^{18}$ The most important of these was "lands over which proclamations have been issued prohibiting alienations other than in favour of the Crown." 19 Such "alienation proclamations" were a tool used by the government when purchasing Māori land. When the government had it in mind to purchase a Māori land block it would be "proclaimed", using the device of an alienation proclamation. Such a proclamation did not prohibit alienation as such, but alienation to any purchaser other than the Crown. "Alienation", moreover, was defined very broadly, and including mortgaging and leasing. Once owners' land had been "proclaimed", their hands were completely tied: they could not sell their property, mortgage it, or lease it. But it remained liable for rates. Crown purchases proceeded piecemeal, as Māori land blocks were multiply owned. A block could have hundreds of owners and the process of Crown purchasing could take years or even decades. With no room for manoeuvre, owners still faced mounting rates bills. Hence, the suggestion that proclaimed blocks, at least, should be exempt from rates.

What were Māori supposed to do with their land when it was locked up by the government in this way? (Using it for subsistence horticulture while carefully hoarding pounds and pennies to pay local authorities to provide for roading for the whole community and for rural water supplies that often Māori rural people did not get?) Arguably, as being inalienable, such land was valueless and could not be reliably assessed. Nonetheless such land continued to be liable for rates, as noted, and rating debts accumulated. Clearly Māori representatives were making a very reasonable point.

Indeed, the January 1928 conference stipulated that any new legislation should provide that "the issue of such proclamations be sufficient notification to local authorities and the Native Land Court for refraining from levying rates or making charging orders". ${ }^{20}$ This too was only reasonable, and it is astonishing that it was not already the case. In fact, often alienation proclamations were carefully

17 Local Elections and Polls Amendment Act 1944, s 3.

18 "Maori Conference: Delegates from Leading Tribes: Native Problems Discussed" Manawatu Herald (Foxton, 5 January 1928) at 3.

19 At 3 .

20 "Maori Conference: Delegates from Leading Tribes: Native Problems Discussed", above n 19, at 3. 
timed, precipitated by urging from local Pākehā keen to buy up Māori properties in their localities. There are instances where a block would be proclaimed at the very moment at which current leases were expiring. The precise object of such proclamations was to prevent particular blocks from being re-let. This left the owners with only one way out: to sell to the government at the government's price and according to the government's achingly slow purchasing timetable. What this shows is the interlocking nature of the tenurial problems that Māori owners faced - even when their lands were not actually vested in a Māori Land Board (the worst possible fate that could befall them) they were nonetheless hemmed in at every turn. Perhaps the most colossal of the ironies of the situation was that although the Native Lands Acts were originally designed to turn Māori into individualised property owners free to do what they wanted with their own private property; Māori landowners subsequently became entangled in a web of interlocking statutory restrictions that prevented the very aspiration that the drafters of the Native Lands Acts of the 1860s claimed to foster.

In 1928, GP Shepherd, at that time Chief Clerk of the Native Department, gave evidence to the Otaki Borough Inquiry, presenting an extremely useful, if rather technical, summary of the law relating to the rating of Māori freehold land. Shepherd's 1928 summation is as follows: ${ }^{21}$

1. Native Land shall be liable for rates in [the] same manner as if it were European land subject to special provisions of Act (sec. 102) ('Native land' means 'customary land or Native freehold land.').

2. Lands exempt from rating: (a) Customary land; (b) Native land, not exceeding five acres in any case, occupied by any Native burial ground; (c) Native land, not exceeding five acres in any case, on which a Church or Native meeting house is erected. (Section 103).

3. Governor-General in Council may exempt Native lands from rating in respect of future rates (Section 104). Native Minister may release land from payment of unpaid rates and local authority may remove such property from rate book (Native Land Amendment and Native Land Claims Adjustment Act, 1926, Section 34).

4. Lands vested in Maori Land Boards, Native Trustee, or East Coast Commissioner: Trustee to pay rates and to be liable only to the extent of net revenues arising from such land - limit four years. May apply revenue in hand towards rates due on other Native land in same ownership (Section 105).

Shepherd went on to explain how charging orders worked:

1. Rates may be recovered (after demand in usual way) by lodging with Registrar of Native Land Court for proper district but not later than two years after rate was levied, a claim for rates against the land. The Court after enquiry may make an order granting a charge over the land in favour of the local authority for amount of rates and costs of order, which shall be registered against the title if on Land Transfer Register, and if not on Register, the Registrar is required to send charging order

21 "Otaki Borough Inquiry: Drainage Matters: Evidence of Natives" Otaki Mail (Otaki, 11 May 1928) at 2-3. 
for registration contemporaneously with title which it affects. The Court in enquiring into claim for rates may transfer liability to any other land, and in special cases may remit whole of rates (Section 108)

2. A charge may be enforced by appointment of a receiver (sub-Section 7 of Section 108).

3. A charge imposed on land has the effect of preventing dealings in the land affected without consent of Court or local authority (sub-Section 8 of 108).

4. If charge not paid off for one year after making, land may be vested in Native Trustee for sale, subject to consent of Native Minister, or Native Trustee may pledge the land for purposes of paying off the charge. (Section 109.)

In April 1928 a committee of inquiry (one of so many to do with Māori land!), referred to variously as the Consolidation Commission or the Native Commission, toured the country, inquiring into the rates problem and consolidation of Māori land titles. This commission was confined only to North Auckland and the King Country, for some reason or other. The consolidation commissioners were all Māori: Sir Maui Pomare (Native Minister in the Reform Government), Sir Apirana Ngata (Member for Eastern Maori), Tau Henare MP, and HW Uru, MP (other sources list the members of the Commission as Ngata, P Te H Jones, W Cooper of the Native Department, H R Balneavis (the Minister's personal secretary), a Mr Danby of the Native Department, and various members of the Consolidation Committee, whatever exactly that was. Navigating one's way around the proliferation of boards, committees, commissions and so forth engaged with Māori land at this time is not always easy and must have puzzled even contemporaries at times.

The Consolidation Commission began its progress around the North Island in April 1928 at the King Country town of Te Kuiti, where the commissioners were given a friendly welcome by Ngati Maniapoto. The opening sessions were described as follows in the King Country Chronicle (12 April 1928): 22

The Native Rating Commission, accompanied by Sir Maui Pomare, Minister of Native Affairs, arrived in Te Kuiti last evening. The personnel of the commission is as follows, Sir Apirana Ngata (chairman), Mr P. Te H. Jones, Mr. W. Cooper, of the Native Department, Mr. Tau Henare M.P., and Mr. H.R. Balneavis, secretary of the Native Minister, Mr. Danby, of the Native Department, and officers of the Consolidation Committee. Members of the commission and Sir Maui were accorded a reception at the local pa this morning, when addresses of welcome were tendered to the visitors by chiefs from various parts of the district. Natives and chiefs from all parts of the King Country are visiting Te Kuiti at present in honour of the Native Minister and members of the commission. The commission, which has been set up with Sir

22 "Gathering of Natives: Visit of Native Land Commission: Welcome at the Pa" King Country Chronicle (12 April 1928) at 5. 
Apirana Ngata at its head, and which has been on a tour of the several districts of the North Island, will meet members of local bodies on Saturday, and the question of native rates will be considered.

In Te Kuiti, however, the Consolidation Commissioners found that the King Country Māori land rating had a special constitutional dimension not found elsewhere. In the King Country, what counted was not the Treaty of Waitangi but rather the Ohaaki Tapu ("Sacred Bequest") of 1884, by which the rangatira of the Rohe Pōtae (the King Country) had ceded their independence to the Crown. According to the Ohaaki Tapu, of such pivotal importance in Te Rohe Pōtae, Māori lands in the King Country were exempted from having to pay rates. ${ }^{23}$ Contemporaries were well aware of this constitutional dimension, peculiar to this region, and thought it unlikely that any agreement with the principal iwi of the King Country, Ngati Maniapoto, would be easily achieved: ${ }^{24}$

\footnotetext{
Judging from some of the speeches delivered at a preliminary gathering, Sir Apirana will not find his task as easy with the Ngati-Maniapotos as his recent achievement with the Ngapuhis. The Maniapotos are more advanced in native land laws, and have had more experience in land dealings than any other tribe. Moreover, the question of rating King Country lands is obnoxious to them - they assert that a definite promise was given them through their chief, Wahanui, by the Hon. J. Bryce and the Hon. John Ballance in 1884 , that if they agreed to the railway passing through their district only the lands they were actually using would be rateable.
}

In May 1928, another commission of inquiry, the Otaki Commission, took evidence at the town of Ōtaki, where rating problems were especially acute. Ōtaki was unusual, as a borough which contained a significant amount of Māori freehold within borough boundaries. The discussions at Ōtaki, which were recorded very fully in the newspapers, demonstrate the intense feelings generated by the Māori land problem. The Commissioners were addressed very forcibly and at some length by Rere Nikitini (Nicholson) of Ngati Raukawa, a prominent citizen and successful farmer, who lectured the Commissioners about the special problems of Māori land rating at Ōtaki, describing the borough's increased rates demands as an "insidious form of confiscation". ${ }^{25}$

The Ōtaki rating issue shows clearly that the Māori land rating problem was not simply one of Māori land tenure and costs, but also was bound up with political control over counties and boroughs.

23 On the unique Māori land tenure situation in the King Country see Richard Boast "The Native Land Court and the King Country 1886-1909" in The Native Land Court: A Historical Study, Cases and Commentary: Vol 2, 1888-1909 (Thomson Reuters, Wellington, 2015) 155 at 155-197. This chapter was largely based on new research carried out for the Waitangi Tribunal Rohe Pōtae [King Country] Inquiry (Wai 898, 2015). The 'King Country' was a political unit, that part of the North Island governed by the Māori King and from which Pākehā were excluded. The Rohe Pōtae or King Country land block, also known as the Aotea bock, was originally investigated by the Native Land Court in 1886 .

24 "Native Lands: Consolidation Commission" Waikato Times (Hamilton, 13 April 1928) at 11

25 "Otaki Borough Inquiry: The Native Viewpoint: Interesting evidence" Horowhenua Chronicle (Levin, 14 May 1928) at 7. 
Forming Ōtaki into a separate borough would have meant that rates would need to be levied to support the expense of a separate borough administration, which perhaps Māori people in the Ōtaki area could not see the point of. Some of Mr Nicholson's testimony gives the impression that some in Ōtaki wanted Māori living within borough boundaries to sell their land and move out of the town, which seems to be the context for Mr Nicholson's remarks. Imposing high rates on Māori landowners within the boundaries of a borough might have the effect, perhaps the intended effect, of forcing Māori to move elsewhere. Mr Nicholson, however, rejected the suggestion that Māori should move outside the borough: "That is the worst thing thought of as it is equivalent to drawing the colour line". "I was," he observed, "always under the impression that Maoris and Pakehas were one, now you [addressing a borough councillor] want to draw the colour line". ${ }^{26}$ Another issue raised by Mr Nicholson was land valuation: if the land within borough limits increased in value, then that made it more difficult for Māori owners within borough limits to sell their properties: if valuations exceeded reasonable market values that was, in his view, tantamount to confiscation: "If the valuation is above the value of the land it makes it more difficult for the Natives to sell; this is happening now." "How," he asked, "was it possible to confiscate Maori lands now?"27 Nicholson went on to say that the Otaki Borough Council was incompetent and that everyone had been better off under the Horowhenua County's administration and advised the commissioners that Māori living in Ōtaki could not pay their rates because many were unemployed. ${ }^{28}$

In 1933, the National Government set up yet another commission, styled the Native Rating Committee, a different Commission from the Consolidation Commission and the Otaki Commission, (there was also a Commission in 1928 dealing the rating of farmlands in boroughs, focusing to a large extent on Feilding), which also travelled about the country and collected yet more evidence and submissions. The Commissioners were Messrs McLeod and Jones and GR Reid, Chairman of the Opotiki Country Council. This 1933 Commission reached the Ngati Porou town of Ruatoria in May. Māori speakers went to considerable lengths and trouble to explain the Māori position on the problem, pointing out, amongst other things, the lack of control Māori ratepayers had over council expenditures, and their inability to restrain councils from taking out expensive (high interest) loans. By now New Zealand was in the depths of the Great Depression and the problems of Māori rating had only got worse. The East Coast being something of a special place; however, Pākehā speakers were careful to emphasise there was no ill-feeling for Māori people over the issue, presumably problems relating to Māori land being a matter of common knowledge. ${ }^{29}$

26 At 7 .

27 "Otaki Borough Inquiry: The Native Viewpoint: Interesting evidence", above n 25, at 7.

28 At 7

29 "Rating Commission, Visit to the Waiapu, Dispute on Compromise, No Ill-feeling for Maoris" Poverty Bay Herald (Gisborne, 23 May 1933) at 5. 
The Native Rating Committee reported in late $1933^{30}$ and its report attracted a certain amount of media attention. The report of the committee was critical of what it saw as a deliberate Māori policy to not pay their fair share of the rating burden. The report was a slight document of only three pages. It could have been written in an afternoon, and certainly came nowhere near to grappling with the complexities of the problem. No effort was made to analyse the points Māori witnesses had made to the Committee. The Committee's principal finding was that because Māori were making full use of facilities provided by the county councils (driving along county roads, for instance), it followed that: ${ }^{31}$

$[u] n l e s s$ the State is prepared to fully meet the responsibilities for Native rates, it is unjust that a policy of non-payment by Natives should cast the liability on European ratepayers of particular districts.

There was nothing really to suggest that Māori had a deliberate policy of not paying their rates. Māori leaders like Rere Nicholson had often stated that they did not oppose paying fairly levied rates. ${ }^{32}$ Moreover, the suggestion that the financially broken State should compensate farmer-dominated local bodies for outstanding Māori rates in the middle of the Great Depression was hopelessly unrealistic.

In fact, the Committee essentially cast the whole problem of collecting rates back on the government. There was a certain amount of logic to that position, albeit that the Committee did not explore the issues in any depth. The real problem was not Māori unwillingness to pay, but rather, the complex system of Māori land tenure itself and the inconsistent policies underpinning it. According to the 1933 Committee Report: ${ }^{33}$

The collection of Native rates has always been a more or less difficult matter, but in recent years with many local authorities it appears that the collecting of an appreciable amount of Native rates has been an impossibility. The charging-order system has hopelessly broken down. Quick and liquid finance is a pressing necessity with most local authorities, particularly those having a large percentage of Native land. Even if timely finance was not a pressing necessity, the ultimate result of the system of carrying the system of charging-order against the land into full effect, must be the entire dispossessment of Natives of their lands. No local authority, however urgently in need of revenue, desires to see Natives dispossessed of their lands, and it is certain that no Government could stand by and watch Native land generally being compulsorily disposed of for rate liabilities. Native advisers are well aware of this fact. A very heavy responsibility will, however, be thrown upon the State, or a weighty load cast on a section of ratepayers already overburdened, if something effective, even if unusual, is not quickly attempted in the direction of ensuring payment of Native-land rates being attempted.

30 "Report of the Committee on Rating of Native Land", above n 14

31 At 3 .

32 "Maoris Should Pay: Native Rates Problem: Special Committee's Opinion" Waikato Independent (Cambridge, 16 December 1933) at 5 .

33 At 5 . 
There is more than a hint here that the best solution might be for the government to cover the rating arrears itself. The argument could have been better developed, emphasising the point that Māori freehold land was not equally distributed around the North Island and some local bodies were faced with a massive problem not of their own making.

Certainly, there were serious problems arising both from Māori land tenure and from the way in which Māori land was distributed; the areas most affected by the Māori rating issue were some North Island rural counties, meaning that counties in Canterbury and Otago were unaffected, as were urban areas, while counties in the East Coast, Whanganui and so forth, faced significant difficulties. These disparities have perhaps impacted on the national infrastructure to this day, as is obvious to anyone familiar with rural Canterbury, Taranaki, and the Waikato on the one hand and the back country in Northland and or the East Coast on the other. At the heart of the whole issue was a wider problem, the State's slowness to develop a workable system of roading infrastructure, well beyond the Committee's terms of reference. The Committee's report referred to a "policy of non-payment by natives", implying that there was a deliberate Māori "policy" of not paying. In truth, rather than constituting a deliberate policy, non-payment was more often simply that Māori could not pay, or that once Māori had defaulted on a payment, the complexities of Māori land tenure made the arrears hard to collect or fix responsibility for.

In February 1934, Forbes (the Prime Minister) and Coates (Native Minister) met with Māori representatives at Waitangi to discuss the rates issue again. Māori suggested that Māori freehold land should simply be exempt from rating. Newspapers were dismissive of that suggestion, but some commentators could see that given the tenurial complexities of Māori land, it was understandable that Māori might feel that "complete de-rating" was the best option: ${ }^{34}$

Representatives of the Maoris recently assembled at Waitangi discussed with the Prime Minister [Forbes] and Mr. Coates the vexed problem of rating on native lands. Their plea that such lands should be completely exempted from rating was extravagant and unreasonable; but for that they are not entirely to blame. The efforts of county councils to collect rates on natives [sic] lands have for so long been blocked by the complexities of Maori land tenure that Maori landowners can be excused for believing that the best solution of the problem is complete de-rating. The confusion into which existing legislation has fallen, a confusion which has been deepened by conflicting native land court judgments, is having three very serious consequences. It is causing acute financial embarrassment to some North Island counties; it is responsible for much injustice to European ratepayers in those countries [sic-counties]; and it is bringing the administration of the law into disrepute among the Maoris.

Notwithstanding councillors and council staff's frequent finger-pointing at Māori ratepayers, much of the blame for the problems collecting Māori rates falls on councils themselves. In much of Northland, for example, Cleaver and Francis have found that councils "generally failed to ensure that

34 "Rating on Native Lands" Thames Star (Thames,12 February 1934) at 2. 
valuation rolls recorded accurate and up-to-date information concerning Māori land". ${ }^{35}$ No doubt this was not a problem confined to Northland. This (very real) problem was largely a by-product of the Māori land tenure system, as result of which it was often far from obvious who the owners of a Māori land block actually were. Another problem was uncertainty about who was responsible for updating the valuation details for Māori freehold land; the responsibility for this onerous task was shared between the Valuation Department, the Native Land Council, and the councils. ${ }^{36}$ Māori ratepayers could seldom be sure that their properties had been rated fairly and accurately, which was certainly another disincentive to pay them.

Moreover, up to 1944, ratepayers who defaulted on their rates were not permitted to vote in county elections, a rule that often further disempowered Māori landowners. Section 9 of the Local Elections and Polls Act 1944 finally introduced a system of voting based on residence (rather than of ratepayers), thus ending, as Cleaver and Francis put it, "ratepayers' exclusive hold on the county electoral system". ${ }^{37}$ However, as Cleaver and Francis have found in their study of Northland, the 1944 legislation did not succeed in fully enfranchising Māori in county elections. They suggest that government officials often failed to communicate the requirements of the 1944 Act to Māori and believe it "unlikely" that "county clerks actively looked to place Maori on country electoral rolls".38 They argue also that the central government was complicit in spreading disinformation about Māori electoral rights after $1944 .{ }^{39}$

\section{RATING AND LAND DEVELOPMENT}

In 1929 Sir Apirana Ngata's great Māori land development programme began. The programme was based on government loans to Māori landowners to facilitate their ability to bring their land into full production. Once the land had been developed and titles consolidated under the supervision of departmental officers from the Departments of Lands, Native Affairs and Agriculture, the loans were repayable as a charge on farm income. Māori land development was given effect to in a massive statute enacted in 1929, s 23 of the Native Land Amendment and Native Land Claims Adjustment Act $1929,{ }^{40}$ which conferred extensive powers on Ngata as Native Minister and on the Māori Land

35 Cleaver and Francis Aspects of Political Engagement between Iwi and Hapu of Te Paparahi o Te Rahi and the Crown, 1910-1975 (Wai 1040, No A50, unpublished report commissioned by the Waitangi Tribunal for The Te Paparahi o Te Raki Inquiry, May 2015) at 71.

36 At 74

37 At 81 .

38 At 82 . I agree that this is indeed most unlikely.

39 At $82-83$.

40 Section 23 of the Native Land Amendment and Native Land Amendment and Native Land Claims Adjustment Act 1929 was welded together to form the Native Land Act 1931, which remained the governing statute for the Māori land system until the enactment of the Maori Affairs Act 1953. The 1953 Act was substantially 
Boards to develop Māori freehold land. This development in essence meant, under government financial support and expert advice, converting the land into dairy farms. It is important neither to downplay the significance of land development during the Ngata era nor to exaggerate its benefits: a balance not easily achieved on the current state of scholarship. Once the actual land development had been done, the employment opportunities generated by the schemes were surprisingly limited. By 1940, according to the Christchurch Press (reporting on some comments by Ngata) only about 2,000 Māori "were on land development schemes". Moreover, many of these people were struggling to make a living and repay the Crown debt, with "the Government taking 40 per cent of the cream cheques". ${ }^{41}$

The 1933 committee's suggestion ${ }^{42}$ was that once Māori land had been developed, then at least 50 per cent of the rates should be the first charge on income from the land. If it had been adopted, this suggestion could have been absolutely crippling to owners and could have undermined the whole land development policy. Furthermore, the suggestion seems to have overlooked the fact that owners of developed blocks would have been paying off government loans. Paying off the rates presumably ranked above paying back the Crown, feeding the children, and paying for essential maintenance and carrying out the suggestions of government inspectors. There was another problem associated with the Native Department's land development schemes (not addressed by the 1933 Committee): after Māori land had been through a land development scheme, then its capital value went up, and therefore, so did the rates. In such a situation Māori owners would face repayment of the Crown loan, paying off rating arrears, and an increasing rates burden in the future.

In 1941, councils once again hit on the plan that, with the assistance of the Native Department, rates would be deducted from cream cheques on developed land blocks in Māori freehold title. As that was precisely what the Native Affairs Department and the Land Boards did to recover advances for Māori land development, Councils presumably thought that they could dip into this funding stream too. But Māori dairy farmers' incomes were by no means infinite. Sir Apirana Ngata had argued that Māori land development was a way out of the Māori land rating problem but presumably, he would not have wanted to see too great a proportion of the benefits flow into the coffers of rural councils and benefit non-Māori farmers. Not all of the benefits of land development should pass into the hands of the Crown, the Land Boards, and local government, one assumes: perhaps, Māori farmers could have wondered, might they be permitted to have some income for themselves? How this unpleasing

amended in 1967 and 1974 and replaced by the current statute in 1993. The Te Te Ture Whenua Māori Bill 2016, designed to significantly curtail the jurisdiction of the Māori Land Court, was unsuccessful.

41 "Settlement of Maoris: Finances of Scheme Criticised: Views of Sir Apirana Ngata" The Press (Christchurch, 27 July 1940) at 12.

42 "Report of the Committee on Rating of Native Land", above n 14, at 3. 
proposal might have worked can be seen from the following discussion of the cream cheques ratesdeduction project printed in the Northern Advocate (13 September 1941): ${ }^{43}$

\footnotetext{
Machinery to endeavour to collect native rates was put into operation by the Whangarei County Council at its monthly meeting yesterday, authority being given the staff to take steps to secure the co-operation of dairy companies by deductions from native cream cheques. The clerk (Mr H. C. Hemphill) reported that he had discussed the question of native rates with an official of the Native Land Court and the assistant clerk (Mr. G. H. Lloyd) had conferred with another official of the court, both officers being most helpful in discussing and outlining the procedure to be followed.
}

This was meant to be a voluntary process, but Māori landowners, some of whom were now paying off state mortgages in any case, were understandably wary. As far as I am aware, the suggestion of deducting rates from cream cheques was never taken any further. The problems remained unresolved.

\section{LOCAL GOVERNMENT (RATING OF WHENUA MAOORI) AMENDMENT ACT 2021}

The most recent instalment in the long and troublesome history of the rating of Māori land occurred as recently as April 2021, with the enactment of the Local Government (Rating of Whenua Māori) Amendment Act 2021. The new statute is an amendment of the current rating statute, the Local Government (Rating) Act 2002. The purpose of the new legislation, according to Nanaia Mahuta, Minister of Local Government, was to end a rating system "that was not fit for Māori" and had "resulted in underdevelopment of Māori land". ${ }^{44}$ However, it remains to be seen whether the new statute will keep at bay the long legacy of the Māori rating problem - a legal equivalent of the Ghost of Christmas Past. ${ }^{45}$ Section 50 of the 2021 Act provides for the remission of rates for Māori freehold land under development - provided that the development creates new homes, supports marae, and facilitates the occupation and development of the land.

Local councils have long had power to write off rates arrears, and often have done so (usually because there has been no option, the rates being so difficult to collect). Given this, it is hard to see what giving councils power to write off rates arrears at this late hour would achieve. Nor at first sight will the new Act have any impact on the long historical process of Māori land being subjected to charging orders or compulsorily vested in the Māori Land Boards for rating debts. Whether this issue has been factored into the current negotiation and settlement process for historical claims, I do not know (it was something that will have happened to everyone). What I hope to have conveyed in this article is the vast scale and intricacy of the Māori rating problem, an undiscovered story that probably

43 "Steps to Gain Payment of Native Rates" Northern Advocate (Whangarei, 13 September1941) at 7.

44 Moana Ellis "Māori Land Rating Bill Corrects '100 Years of Disadvantage'" New Zealand Herald (online ed, 7 April 2021).

45 Charles Dickens A Christmas Carol (Oxford, Macmillan Heinemann ELT, 2005). 
deserves a Waitangi Tribunal Inquiry all to itself. At the very least, rating of Māori land must be seen as an important component of the legal history of the New Zealand taxation system. The legal history of taxation in a colonial society like New Zealand must take account of the different impacts certain kinds of taxes have had on different portions of the population. For Māori living in the countryside in circumstances of quite dire rural poverty, rates had a peculiar impact that differentiated Māori from other sectors. One might contrast that with, for example, the legal history of estate and gift duties, which touched the Māori population very slightly, or not at all. Similarly, for the Pākehā well-to-do, while paying rates may have been irksome, rates would not have been seen as an issue of much significance. Moreover, that already privileged population would benefit from rising capital values, while Māori barely could, given that the State controlled the Māori land market and Māori lacked access to development credit in any case. It is this differential impact of rating on Māori which makes the subject both interesting and important. What subject could be more utterly prosaic and uninviting than rating of Māori freehold land? But in fact, it is a very illuminating subject and one which can even be said to be fascinating. 